\title{
The Development of Audio-Visual Learning Media Tutorial Crawl Swimming Basic Skills Swimming Course of PKO FIK UNIMED Program 2021
}

\author{
Zulfan Heri ${ }^{1,2, *}$ M N Hasibuan ${ }^{1}$ Puji Ratno ${ }^{1}$ Shilvia Kumala ${ }^{1}$ T Br Aruan ${ }^{1}$ \\ ${ }^{1}$ Faculty of Sport Education Departement, Universitas Negeri Medan, Indonesia \\ ${ }^{2}$ Chief of the Member \\ ${ }^{*}$ Corresponding author. Email: zulfanheri5@gmail.com
}

\begin{abstract}
Swimming is one of the sports that must be studied by every student in the Sports Coaching Education Study Program (PKO) FIK UNIMED. This study aims to develop audio-visual learning media, back stroke tutorials, for the basic swimming skills course, PKO FIK UNIMED 2021 academic year study program. The implementation of learning using audio-visual media requires students to be able to perform back stroke swimming skills by learning independently and maximally by watching by observing videos that have been made and arranged systematically as demands in meeting the development of science and technology as well as the existing curriculum. Video is an audio-visual media that is able to convey information clearly through films, images and sound. This study using Research and Development (R\&D) that adapted 4D model. The instruments used are in the form of assessment sheets or learning media assessment questionnaires for material experts, media experts, lecturers/teachers, and students. Qualitative data analysis in the form of criticism and suggestions from media experts, material experts, trainers and students. The results showed four 4D steps, namely Define, Design, Development, and Disseminate. The results of the research analysis are developing learning media using audio-visual tutorial swimming back stroke for basic swimming skills in the PKO FIK UNIMED study program, with an assessment of material experts in the good category of 3.4, and the assessment of media experts of 3.34 in the good category.
\end{abstract}

Keywords: Audio Visual Media Tutorial Swimming Back Stroke.

\section{INTRODUCTION}

In educational activities, learning activities must be carried out by each individual to obtain a change in the level of behavior towards maturity. Learning is a process in which the provision of training or experience occurs that leads to changes in behavior in a person that are relatively permanent in one's ability to display knowledge, movement and attitude skills. According to Vernon S. Gerlach \& Donald P. Ely in their book is Teaching \& Media-A Systematic Approach (1971) in Arsyad (2011) said that; "Learning is a change in behavior, whereas behavior is an observable action. In other words, behavior is an observable action or result caused by an observable action or several actions."

In the implementation of basic swimming skills learning, several strategies or methods are needed in using various learning media. In general, learning media is a tool for teaching and learning process. Everything that can be used to stimulate the thoughts, feelings, attention and abilities or skills of the learner so that it can encourage the learning process. Bringgs (1977) in Sadiman (2008) states that; "learning media is a physical means to deliver learning content/materials such as; books, movies, videos and so on."

The basic swimming skills course is one of the compulsory subjects to be followed and studied by every student in of Sports Coaching Education in FIK UNIMED, to be able to master the skills and knowledge students are required to have cognitive abilities and motor skills in sports. In addition to the success of learning sports, students are also determined by interest in learning, intelligence, motivation and educational background that they follow (S. Safarinah, 1986). 
From the results of the implementation of online learning that has been carried out by utilizing learning media in the form of audio visuals conducted on students of Sports Coaching Education in FIK UNIMED, there are only 2 (two) swimming styles that have been carried out in research relating to the development of teaching materials in the form of breaststroke learning media, and crawl, from the results of the implementation of lectures carried out in odd semesters, the results of swimming scores, especially in learning the breaststroke and crawl are good with a percentage level of mastery and graduation of $85 \%$.

The audio-visual learning media for backstroke swimming tutorials that are carried out displays various swimming techniques and movements contained in the video (youtube) that will be produced. The messages presented can be factual or fictitious, can be informative, educative or instructional. Audio-visual learning media is a series of motion accompanied by sound that forms a single unit that is assembled into a plot, with messages in it for the achievement of learning objectives that are stored with the process of storing data in tape or disk media, video is an audio-visual media that displays motion Sadiman, 2008) seeing the importance of teaching materials in the form of swimming learning media during the implementation of online learning, the researchers conducted research to develop audio-visual learning media for backstroke swimming tutorials in the basic swimming skills course in the of Sports Coaching Education in FIK UNIMED.

\section{RESEARCH RELATED}

Mastery of skills is determined by many factors, including factors from students themselves as students, as well as factors from teachers (educators), infrastructure factors, environmental factors, learning strategy factors, and others. One of the important learning strategies in mastering backstroke swimming learning skills is to apply learning media, especially in the implementation of online learning in this semester, namely by using audio-visual learning media as teaching materials. Gagne and Brigs. (1992) states learning media includes tools that are physically used to convey the contents of learning materials, including: books, tape recorders, cassettes, video cameras, video recorders, films, slides, photos, pictures, bar charts, television and computers. Learning media can also be said as materials, tools/media, and methods/techniques used in teaching and learning activities with the intention that the process of educative communication interaction between students and lecturers can take place effectively and efficiently in accordance with the teaching objectives that have been planned.

Video can served the information, explain the process, explain the difficult concepts, teach the skill and affect the attitude. The tools that include audio visual are
TV, VCD, sound-slide, and movies. In the development of this learning media in the form of this video, after the video is finished, the results will be displayed via Video Compact Disk (VCD). Video sources can be divided into three, namely: (1) Moving images, this image comes from a camcorder and is also accompanied by sound. So this moving image is often called a video. The moving image consists of a series of images in bitmap format. (2) Still image, this image is sourced from a digital camera or often called a photo. This still image can be made into a video or moving image in the form of a slide or commonly called a photo slide. (3) Engineer images (animation, cartoon, etc) for this one image are not included in the type of image taken from nature (natural image) like the two image sources above. The tool used to produce this image is a computer using software such as Photoshop, 3Ds max and others. The resulting images are our own creations and can be in the form of moving, still and sound.

\section{METHOD}

\subsection{Research Time and Place}

The time of the research was carried out in the odd semester of the 2021--2022 academic year in UNIMED, study program of Sports Coaching Education. The place where the research was carried out was at the State University of Medan (UNIMED) Swimming pool, Jl. Williem Iskandar Pasar V Medan Estate.

\subsection{Research Subject}

To carry out a needs analysis, observations were made by lecturers who support basic swimming courses at the UNIMED Faculty of Sports Science as many as 2 swimming experts and 1 media expert and PKO FIK UNIMED students in 2021.

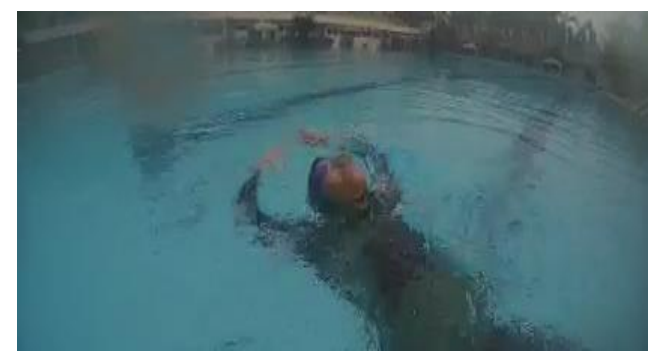

Figure 1. Backstroke Swimming Style

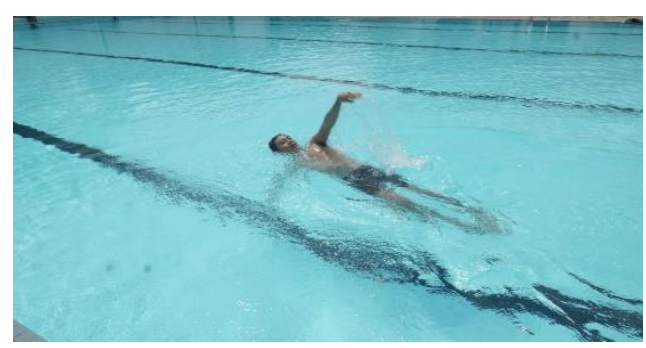

Figure 2. Backstroke Swimming Style 


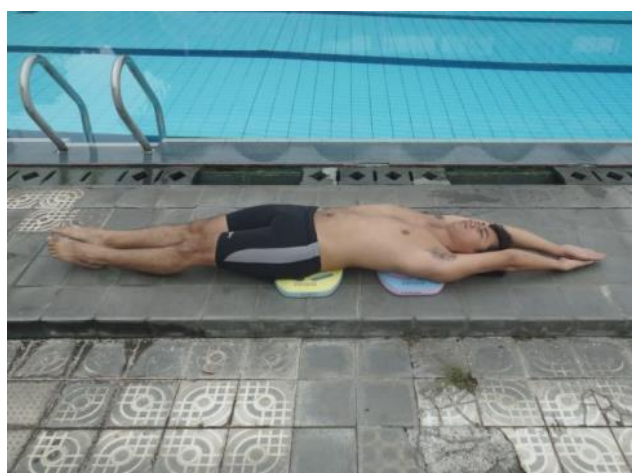

Figure 3. Ready Position

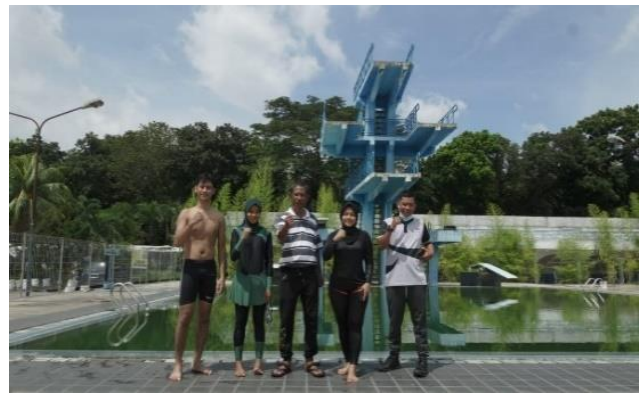

\subsection{Research methods}

This research is a research and development $(\mathrm{RnD})$ means this research is a product-oriented research. Endang Mulyatiningsih (2012) explained 4 steps of development, namely the 4D model.

\subsection{Research procedure}

This research was conducted to produce a product in the form of a Video Compact Disk (VCD) for learning backstroke swimming tutorials for PKO FIK UNIMED students in 2021. The activities carried out included activities to compose and create learning media for crawl swimming VCD tutorials based on needs analysis by collecting data from stakeholders, lecturers of basic swimming courses from 3 (three) study programs at FIK UNIMED related to the curriculum (syllabus and RPS) used so far. The manufacture of VCD products still pays attention to the sequence and depth of the material and images. The data that has been compiled is then held in seminars to produce teaching materials in the form of VCDs as a good backstroke swimming tutorial learning media and in accordance with the demands of the competencies contained in the curriculum.

Figure 4. Team Research

Table 1. Activity Details and Research Achievement Indicators

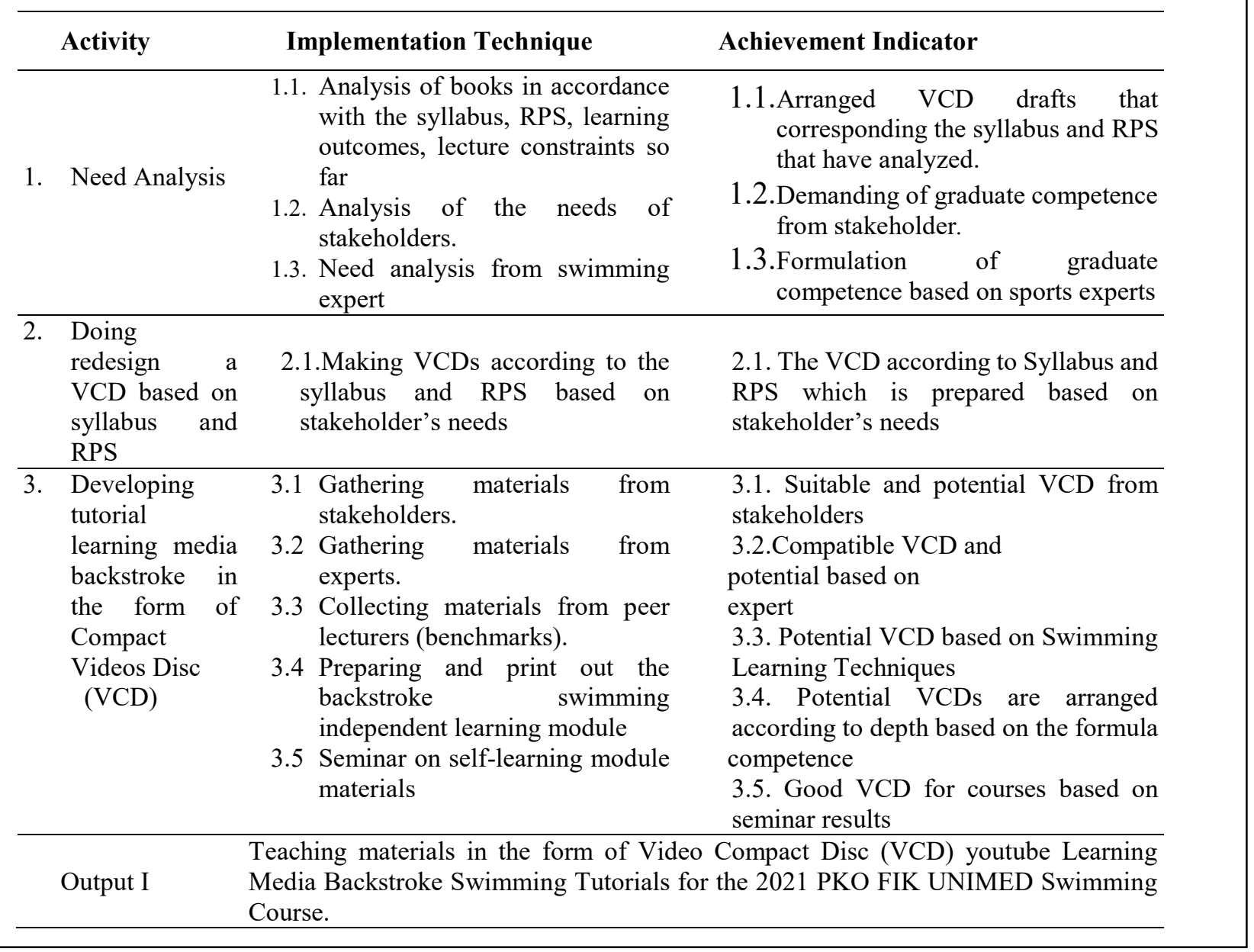




\section{RESULT AND DISCUSSION}

\subsection{The Results of Data Analysis by Material Expert Validation}

The data from the validity of the material experts consist of two aspects, namely the content aspect of the learning media, and the quality aspect of the audio-visual learning media. audio-visual learning tutorial swimming backstroke in basic swimming skills from the content aspect of learning media is "good" with a score of 3.9. While the material expert's assessment of the quality aspect of the learning media is included in the "good" category with a score of 3.05 .

\subsection{The Results of Data Analysis of Usage Trial Results}

The trial stage of using audio-visual learning media, backstroke swimming tutorial, for basic swimming skills courses for PKO UNIMED students who have the same characteristics, namely students who take basic swimming skills lectures. This trial was followed by twenty-five PKO FIK UNIMED students. Student assessment of the material shows that the audio-visual learning media for backstroke tutorials in basic swimming skills courses has good quality, with an average score of 3.9.Student assessments regarding the learning aspect showed that the quality of the audiovisual learning media for backstroke swimming tutorials for PKO UNIMED students was very good with an average score of 4.1.Based on the overall results of the quality results of the audio-visual learning media for backstroke swimming tutorials from the product trial results, it is included in good criteria, with an average rating score of 4 . For more details, see the table below;

Table 2. The Quality of Audio Visual Tutorial Learning Media Products in Trial Usage

\begin{tabular}{lcc}
\hline \multicolumn{1}{c}{$\begin{array}{c}\text { Aspect of } \\
\text { Assesment }\end{array}$} & Average Score & Criteria \\
\hline Material Aspect & 3,9 & Good \\
Learning Aspect & 4,1 & Good \\
Avarage & 8.0 & Good \\
ScoreAspect & & \\
Avarage & 4 & Good \\
\hline
\end{tabular}

\section{CONCLUSION}

To get the results of backstroke swimming, you must practice well, independently and continuously by carrying out several stages of swimming learning that have been prepared by the RPS (Semester Learning Plan). by developing the backstroke toturial audio-visual media, it can be concluded, the audio-visual quality of the backstroke swimming tutorial in the basic swimming skills subject based on the assessment of media experts is 3.9 , which is included in the good category. The audiovisual quality of the backstroke swimming tutorial in the basic swimming skills subject based on the assessment of material experts is 3.05 , which is included in the good category. The results of this study in the form of a backstroke swimming learning VCD for basic swimming skills courses can contribute to the implementation of blended learning, especially in the implementation of online learning.

\section{REFERENCES}

[1] Arsyad, A. (2011). Media Pembelajaran. Jakarta: Rajawali Pers.

[2] Cheppy Riyana,2007. Pedoman Pengembangan Media Video. Jakarta P3AI UPI

[3] Daryanto (2013). Media Pembelajaran. Yogyakarta.Penerbit Gaya Media

[4] Endang Mulyatiningsih (2012).Metode Penelitian Terapan Bidang Pendidikan, Bandung Alfabeta

[5] Gagne, Robert M; Briggs Leslie J. \& Wager Walter W. (1992). Principles of instructional design. (Rev.ed.). Orlando: Harccourt Brace Jvanovich College Publisher.

[6] Munir.2012. Multimedia Konsep dan Aplikasi Dalam Pendidikan. Bandung.Alfabeta

[7] M. Murni. 1992. Renang dan Metodik. Jakarta: Depdikbud.

[8] Nana Sudjana (2004). Penilaian Hasil Belajar,Bandung: Remaja Rosdakarya Paul

[9] S. Arikunto, 2010. Dasar-dasar Evaluasi Pendidikan (Jakarta PT.Bumi Aksara)

[10] Ibrahim R danNana Syaodih 1993. Perencanaan Pengajaran, Bandung PT Remaja Rosdakarya.

[11] Safarinah, 1986. Psikologi Olahraga. Buku Tuntunan Dep P \& K Jakarta.

[12] Soejoko Hendromartono. 1992. Olahraga Pilihan Renang. Depdikbud: Proyek Pembinaan Tenaga Kependidikan.

[13] Sugiyono (2009). Metode Penelitian Kuantitatif Kualitatif \& RnD. Bandung: Alfabeta

[14] Sadiman (2008). Media Pendidikan, Jakarta; PT Raja Grafindo Persada

[15] Thomas, David. G.1996. Renang Tingkat Mahir. Jakarta: PT. Rajagrafindo. 